\title{
KORELASI PENGUASAAN MATERI PEMBELAJARAN OLEH GURU DENGAN MOTIVASI BELAJAR SISWA MATA PELAJARAN ADMINISTRASI PERKANTORAN DI SMK PELITA BOGOR
}

\author{
Arsyad $^{1}$ \\ Wahyu Bagja Sulfemi ${ }^{2}$ \\ STKIP Muhammadiyah Bogor \\ Arsyad_20006@yahoo.com \\ wahyubagja@gmail.com
}

\begin{abstract}
Abstrak : penelitaian ini meneliti tentang korelasi persepsi siswa tentang penguasaan materi guru Mata Pelajaran Administrasi Perkantoran Terhadap Motivasi Belajar Siswa Administrasi Perkantoran di SMK Pelita Ciampea Kabupaten Bogor. Jenis penelitian ini adalah penelitian kuantitatif. Penelitian ini merupakan penelitian sampel karena responden yang berjumlah 57 siswa diambil dari $30 \%$ jumlah populasinya yaitu 191 siswa. Pengumpulan data dilakukan dengan menggunakan metode angket atau kuesioner untuk memperoleh data variabel $X$ yaitu penilaian siswa terhadap penguasaan guru tentang materi pelajaran administrasi perkantoran dan begitupun dengan variabel $\mathrm{Y}$ yaitu motivasi belajar siswa administrasi perkantoran. Adapun perolehan frekuensi variabel $\mathrm{X}$ dengan skor tertinggi 91 dan skor terendah 55, diperoleh rata-rata(mean) 77,39 median 78,9 dan modus 80,9, sedangkan untuk variabel Y skor tertinggi 87 dan skor terendah 56, diperoleh rata-rata (mean) 69,26 median 71,03 dan modus 73. Terdapat atau ada hubungan positif antara penilaian siswa terhadap penguasaan guru tentang materi pelajaran administrasi perkantoran dan motivasi belajar siswa administrasi perkantoran kelas XII Administrasi Perkantoran di SMK Pelita Ciampea Kabupaten Bogor. Hal ini dapat dibuktikan dengan derajat kebebasan $(\mathrm{dk})=\mathrm{N}-2$ dan $\alpha=0,05$ sebesar 2,000 $t_{\text {hitung }}(4,5961)>t_{\text {tabel }}(2,000)$ maka koefisien korelasi adalah signifikan, nilai $r_{\text {hitung }}$ adalah 0,5271 sedangkan $r$ tabel adalah 0,266 dengan batas signifikan $5 \%$ artinya nilai $r_{\text {hitung }}$ lebih besar dari $r_{\text {tabel }}$ yakni 0,5271>0,266 Dengan demikian hasilnya dinyatakan signifikan dan hipotesis yang diajukan diterima.
\end{abstract}

Kata Kunci : Guru, Motivasi Belajar, dan Administrasi Perkantoran

Abstract: This research examines the correlation of students' perceptions of the mastery of office administration subject matter teachers on learning motivation in office administration students at the Mandala Leuwiliang Vocational High School, Bogor. This type of research is quantitative research. This research is a sample study because respondents who numbered 57 students were drawn from $30 \%$ of the total population of 191 students. Data collection is done by using the questionnaire method or questionnaire to obtain variable $\mathrm{X}$ data, namely student assessment of teacher mastery of office administration subject matter and also with variable $\mathrm{Y}$, namely student administration office learning motivation. The acquisition of frequency $\mathrm{X}$ with the highest score of 91 and the lowest score of 55, obtained a mean (mean) of 77.39 median 78.9 and mode 80.9, while for variable Y the highest score was 87 and the lowest score was 56, obtained on average (mean) 69.26 median 71.03 and mode 73. There is or there is a positive relationship between student assessment of teacher mastery of office administration subject matter and student motivation in office administration class XII Office Administration at Mandala Leuwiliang Vocational High School Bogor. This can be proven by degrees of freedom $(\mathrm{dk})=\mathrm{N}-2$ and $\alpha=0.05$ of 2,000 tcount $(4.5961)>$ ttable $(2,000)$ then the correlation coefficient is significant, the value of $r$ count is 0.5271 while $r$ table is 0.266 with a significant limit of $5 \%$ means that the calculated $r$ value is greater than $r$ table which is $0.5271>0.266$ Thus the results are declared significant and the proposed hypothesis is accepted.

Keywords: Teachers, Learning Motivation, and Office Administration

Jurnal Ilmiah Edutecno. Volume 20. No. 2. Tahun 2019. ISSN: 2302-2825 


\section{PENDAHULUAN}

Sekolah merupakan lembaga pendidikan formal yang tidak hanya memberikan pengetahun pada siswa akan tetapi juga membentuk nilai-nilai dan budi pekerti. UU No 20 tahun 2003 Menyebutkan bahwa "Pendidikan adalah usaha sadar dan terencana untuk mewujudkan suasana belajar dan proses pembelajaran agar peserta didik secara aktif mengembangkan potensi dirinya untuk memiliki kekuatan spiritual keagamaan, pengendalian diri, kepribadian, kecerdasan, akhlak mulia serta keterampilan yang diperlukan dirinya, masyarakat, bangsa dan negara. Pendidikan bermaksud membentuk peserta didik untuk menumbukan dan mengembangkan potensi-potensi yang dimiliki”. (Republik Indonesia, 2006: 5)

Potensi tersebut merupakan benih yang akan tumbuh di kemudian hari. Oleh sebab itu untuk menumbuhkan potensi dan mengembangkannya diperlukan adanya fasilitator yang mempunyai kompetensi sesuai dengan bidang keilmuannya.

Guru adalah orang yang mempunya peranan penting dalam menumbuhkan dan mengembangkan potensi yang dimiliki siswanya. Peran guru disekolah sangatlah strategis, oleh karena itu guru dituntut untuk memiliki empat kompetensi sesuai standard kompetensi yang tertuang dalam Undang-undang Nomor 14 Tahun 2005 tentang Guru dan Dosen pada Bab IV Pasal 10 ayat (1), yang menyatakan bahwa "Kompetensi guru meliputi kompetensi pedagogik, kompetensi kepribadian, kompetensi sosial, dan kompetensi profesional yang diperoleh melalui pendidikan profesi”. Keempat bidang kompetensi di atas tidak berdiri sendiri, melainkan saling berhubungan dan saling mempengaruhi satu sama lain dan mempunyai hubungan hierarkis, artinya saling mendasari satu sama lainnya. (Republik Indonesia, $2006: 5$ )

Guru merupakan faktor yang sangat dominan dan penting dalam pendidikan formal pada umumnya, karena bagi peserta didik guru sering dijadikan tokoh teladan bahkan menjadi tokoh identifikasi diri. Oleh karena itu guru seyogyanya memiliki perilaku dan kompetensi yang memadai untuk mengembangkan peserta didik secara utuh. Untuk melaksanakan tugasnya secara baik sesuai dengan profesi yang dimilikinya, guru perlu menguasai berbagai hal terutama kompetensi kepribadian, sosial dan profesional. 
Dalam proses belajar-mengajar, guru mempunyai tugas untuk mendorong, membimbing, dan memberi fasilitas belajar bagi siswa untuk mencapai tujuan. Guru mempunyai tanggung jawab untuk melihat segala sesuatu yang terjadi dalam kelas untuk membantu proses perkembangan siswa. Demikian dalam proses belajar-mengajar guru tidak terbatas sebagai penyampai ilmu pengetahuan akan tetapi lebih dari itu, ia bertanggung jawab akan keseluruh perkembangan kepribadian siswa. Ia harus menciptakan proses belajar sedemikian rupa sehingga dapat merangsang siswa untuk belajar secara aktif dan dinamis dalam memenuhi kebutuhan dan menciptakan tujuan.

Guru di SMK Pelita Ciampea Kabupaten Bogor dalam hal ini punya cara yang berbeda-beda dalam penyampain materi kepada siswa khususnya pada progra keahlian administrasi perkatoran, sehingga pada hal ini ada beberapa faktor yang menjadi dasar pelaksanaan pembelajaran yang baik diantaranya Faktor guru, penggunaan strategi yang digunakan menggunakan strategi pengajaran dengan metode yang masih sangat sederhana dan cenderung monoton, sehingga tidak mengembangkan kemampuan-kemampuan penguasaan konsep. Faktor siswa, dimana pola fikir siswa yang cendrung praktis sehingga belum terbiasa dalam penguasaan konsep dalam proses pembelajaran yang dilakukan guru dalam menyampaian pelajaran administrasi perkantoran sehingga hal tersebut akan berdampak pada motivasi belajar siswa administrasi perkantoran. Faktor waktu, ketersediaan waktu yang sangat terbatas dalam mengikuti dan menguasi mata pelajaran administrasi perkantoran namun materi yang harus dikuasai oleh siswa begitu banyak sehingga dalam proses pembelajaran menjadi suatu aktivitas yang agak sulit dilakukan. Hal ini akan berdampak pada motivasi belajar siswa dalam mengikuti pelajaran kurang maksimal. Apabila siswa tidak bersemangat dalam mengikuti pelajaran yang disajikan oleh gurunya maka tujuan dari pendidikan tidak akan tercapat sepenuhnya.

Sedemikian banyaknya pembahasan tentang motivasi dalam pembelajaran itu telah menghasilkan definisi motivasi yang banyak pula. Namun demikian, pada intinya motivasi dapat diartikan sebagai: “(1) Dorongan yang timbul pada diri seseorang, secara disadari atau tidak disadari, untuk melakukan tindakan dengan tujuan tertentu; (2) Usaha-usaha yang dapat menyebabkan seseorang atau kelompok orang tertentu tergerak melakukan sesuatu karena ingin mencapai tujuan yang di inginkan.”(Mohammad Asrori, 2009 : 183) 
Dari dua definisi motivasi di atas, menjadi jelas bahwa motivasi dapat dibagi menjadi dua jenis yaitu: (1) Motivasi yang berasal dari dalam diri seseorang dan (2) Motivasi dari diluar yang berupa usaha pembentukan dari orang lain.

Dalam buku Belajar dan Pembelajaran, Ali Imron (1996) mengemukakan enam unsur atau faktor yang mempengaruhi motivasi dalam proses pembelajaran. Keenam faktor tersebut adalah sebagai berikut:

a. Cita-cita / aspirasi pembelajar.

b. Kemampuan pembelajaran.

c. Kondisi pembelajar.

d. Kondisi lingkungan pembelajar.

e. Unsur-unsur dinamis belajar / pembelajaran.

f. Upaya guru dalam membelanjarkan pembelajar.

Belajar merupakan sebuah proses yang kompleks yang terjadi pada semua orang dan berlangsung seumur hidup, sejak masih bayi (bahkan dalam kandungan) hingga liang lahat. Salah satu petanda bahwa seseorang telah belajar sesuatu adalah adanya perubahan tingkah laku dalam dirinya. "Perubahan tingkah laku tersebut menyangkut perubahan yang bersifat pengetahuan (kognitif) dan keterampilan (pisikomotor) maupun yang menyangkut nilai dan sikap (afektif).”.’(Mohammad Asrori, 2009 : 183)

Belajar adalah sebuah proses yang kompleks yang didalamnya terkandung beberapa aspek. Aspek-aspek tersebut adalah:”

1) Bertambahnya jumlah pengetahuan,

2) Adanya kemampuan mengingat dan memproduksi,

3) Adanya penerapan pengetahuan,

4) Menyimpulkan makna,

5) Menafsirkan dan mengaitkannya dengan realitas, dan

6) Adanya perubahan sebagai pribadi. (Siregar dan Hartini Nara, $2010: .3$ ).

Guru yang berkompetensi pedagogik baik akan dapat memunculkan motivasi peserta didik dalam mengikuti pelajaran. Guru adalah pendidik yang berkembang, tugasnya sebagai guru mengharuskan dia belajar sepanjang hayat, karena hal tersebut sejalan dengan tututan zaman. Sebagai pendidik upaya guru dalam membelajarkan siswa meliputi ha-hal 
berikut: (1) Menyelenggarakan tertib belajar disekolah (2) Membina disiplin belajar dalam tiap kesempatan, seperti pemanfaatan waktu (3) Membina belajar tertib pergaulan (4) Membina belajar tertib lingkungan sekolah

\section{METODOLOGI PENELITIAN}

Peneliti ini menggunakan metode suvei dengan pendekatan studi korelasi yang merupakan bagian dari jenis penelitian deskriptif kualitatif. Populasi pada penelitian ini adalah siswa kelas XII program keahlian Administrasi Perkantoran di SMK Pelita Ciampea Kabupaten Bogor yang berjumlah 191 Orang. Dalam penelitian ini, penulis mengambil 30 $\%$ dari jumlah populasi yang ada, yakni 57 Siswa yang penentuannya dilakukan secara random (random sampling).

\section{HASIL PENELITIAN DAN PEMBAHASAN}

Data yang diperoleh dalam penelitian ini merupakan data yang didapatkan dengan berbagai metode pengumpulan data meliputi angket dan observasi. Terkait dengan hal tersebut, hasil angket merupakan data primer yang sangat penting karena menjadi bagian utama dalam kegiatan analisis data sedangkan observasi merupakan data pendukung yang peneliti gunakan selama melakukan penelitian dilapangan. Bentuk angket yang digunakan dalam penelitian ini adalah tertutup. Bentuk angket tertutup, dimana dalam angket tersebut sudah disediakan jawaban dan responden menjawab pertanyaan dengan cara memberikan tanda ceklis pada pilihan jawaban yang tersedia. Peneliti mengumpulkan data dari dua sumber, yakni perolehan angket persepsi siswa terhadap penguasaan guru tentang materi pelajaran administrasi perkantoran dan motivasi belajar siswa administrasi perkantoran. Sebelum instrumen angket digunakan untuk penelitian, maka terlebih dahulu diuji cobakan untuk mengukur validitas dan reliabilitas sebuah instrumen. Adapun jumlah pertanyaan yang digunakan dalam uji coba angket ini sebanyak 20 item pertanyaan untuk variabel $\mathrm{X}$ (Persepsi siswa tentang penguasaan guru terhadap materi pelajaran administrasi perkantoran) dan 15 item pertanyaan untuk variabel Y (Motivasi belajar siswa administrasi perkantoran) Adapun hasil dari uji coba instrumen tersebut terdapat 1 item pertanyaan yang 
tidak valid yaitu item nomor 14. Pada angket variabel Y (Motivasi belajar siswa administrasi perkantoran) semua pertanyaan dinyatakan valid.

Dari data didapat nilai kuantitatif persepsi siswa tentang penguasaan guru terhadap materi pelajaran administrasi perkantoran yang terdiri dari 57 siswa sebagai sampel dipreoleh skor terendah sebesar 55 dengan skor tertinggi sebesar 91, range skor sebesar 37, skor rata-rata (mean) sebesar 75,01, median sebesar 79,89, dan modus sebesar 81,45. Penilaian siswa terhadap penguasaan guru tentang materi pelajaran administrasi perkantoran berkisar antara 79 - 83. Untuk mengetahui kecendrungan persepsi siswa tentang penguasaan guru terhadap materi pelajaran administrasi perkantoran secara keseluruhan dapat diketahui melalui perhitungan persentase yang memiliki rentang nilai 0 96. Hasil perhitungan menunjukan bahwa persepsi siswa tentang penguasaan guru terhadap materi pelajaran administrasi perkantoran sangat tinggi sebesar 5,26\%, berkeriteria tinggi sebesar 8,77\%, dan 33,33\%, berkeriteria sedang sebesar 17,54\%, 21,05\%, 7,01\% dan 3,50\%. Kemudian 3,50\% termasuk kedalam kriteria rendah.

Deskripsi Data Motivasi Belajar Siswa Administrasi Perkantoran. Untuk mendapatkan data motivasi belajar siswa administrasi perkantoran, siswa di berikan 15 item pertanyaan mengenai motivasi belajar yang disebar ke 57 siswa administrasi perkantoran. Adapun data hasilnya sebagai dari 57 siswa sebagai sampel dipreoleh skor terendah sebesar 56 dengan skor tertinggi sebesar 87, range skor sebesar 32, skor rata-rata (mean) sebesar 69,26, median sebesar 71,03, dan modus sebesar 73 sedangkan besar simpang baku penyebaran data skor motivasi belajar siswa administrasi perkantoran

Berdasarkan gambaan di atas, dapat dilihat bahwa banyaknya persepsi siswa tentang penguasaan guru terhadap materi pelajaran administrasi perkantoran berkisar antara 79 - 84. Untuk mengetahui kecendrungan persepsi siswa tentang penguasaan guru terhadap materi pelajaran administrasi perkantoran secara keseluruhan yang memiliki rentang nilai 0 - 90. Hasil perhitungan menunjukan bahwa persepsi siswa tentang penguasaan guru terhadap materi pelajaran administrasi perkantoran administrasi perkantoran sangat tinggi sebesar 1,75\%, berkeriteria tinggi sebesar 3,50\%, berkeriteria sedang sebesar 24,56\%, $17,54 \%$ dan $21,05 \%$. Kemudian $14,03 \%$ termasuk kedalam kriteria rendah. 
Data yang sudah terkumpul kemudian peneliti olah untuk mengetahui hubungan persepsi siswa tentang penguasaan guru terhadap materi pelajaran administrasi perkantoran dan motivasi belajar siswa administrasi perkantoran kelas XII SMK Pelita Ciampea Kabupaten Bogor, maka dilakukan perhitungan korelasi product moment, yaitu: dengan hasil 0,5271

Selanjutnya untuk menyatakan besar kecilnya sumbangan variabel $\mathrm{X}$ terhadap $\mathrm{Y}$ dapat ditentukan dengan rumus koefisien diterminan. Dengan hasil 27,78\%. Artinya hubungan persepsi siswa tentang penguasaan guru terhadap materi pelajaran administrasi perkantoran $27,78 \%$ dan sisanya $72,22 \%$ dintentukan oleh variabel lain yang terjadi terhadap motivasi belajar siswa. Secara nyata motivasi belajar siswa 27,78 \% oleh persepsi siswa tentang penguasaan guru terhadap materi pelajaran administrasi perkantoran.

Untuk menguji keberartiannya sebelum ditafsirkan, maka terlebih dahulu dilakukan uji t pada taraf signifikan, yaitu: 4,5961. $\mathrm{t}$ tabel pada taraf signifikan 0,05 dengan $\mathrm{dk}=\mathrm{N}-$ $2=57-2=55$ adalah 2,000 dari hasil perhitungan diperoleh $t_{\text {hitung }} 4,5961$, sedangkan $t_{\text {tabel }}$ 2,000 yang berarti thitung $(4,5961)>t_{\text {tabel }}(2,000)$ maka koefisien korelasi adalah signifikan. Dengan demikian, terdapat hubungan positif antara pesepsi siswa tentang penguasaan guru terhadap materi pelajaran administrasi perkantoran dan motivasi belajar siswa administrasi perkantoran kelas XII SMK Pelita Ciampea Kabupaten Bogor.

Berdasarkan hasil penelitian yang penulis lakukan, dapat dikemukakan bahwa terdapat hubungan positif antara variabel $X$ (persepsi siswa tentang penguasaan guru terhadap materi pelajaran administrasi perkantoran) terhadap variabel Y (Motivasi belajar siswa administrasi perkantoran) karena hipotesis alternatif $\left(\mathrm{H}_{1}\right)$ diterima dengan $\mathrm{r}_{\mathrm{xy}} 0,5271$ lebih besar dari " $r$ " tabel baik taraf 5\% $(0,266)$ maupun taraf $1 \%(0,345)$. Sedangkan hubungan yang diberikan oleh variabel X terhadap variabel Y sebesar 27,78 \% dan sisanya $72,22 \%$ dintentukan oleh variabel lain atau variasi yang terjadi terhadap motivasi belajar siswa. Dengan nilai terendah dari variabel $X$ adalah 55, nilai tertinggi 91 , modus 73 , median 71,03 dan mean 77,39. Dilihat dari rata-ratanya sebesar 77,39 yang termasuk kriteria tinggi. Dengan demikian dapat disimpulkan bahwa persepsi siswa tentang penguasaan guru terhadap materi pelajaran administrasi perkantoran kelas XII SMK Pelita Ciampea Kabupaten Bogor tergolong kedalam kriteria tinggi. 
Berdasarkan hasil penelitian di atas, bahwa motivasi belajar siswa administrasi perkantoran kelas XII SMK Pelita Ciampea Kabupaten Bogor dipreoleh nilai terendah dari variabel Y adalah 56 nilai tertinggi sebesar 87, range 32, rata-rata (mean) sebesar 69,26, median sebesar 71,03, dan modus sebesar 73. Dengan demikian dapat dikatakan bahwa proses pembelajaran yang dilakukan oleh guru administrasi perkantoran SMK Pelita Ciampea Kabupaten Bogor sudah cukup baik.

Pembuktian Hipotesis dari hasil perhitungan product moment di atas diketahui bahwa nilai $\mathrm{r}$ hitung adalah 0,5271 sedangkan $\mathrm{r}_{\text {tabel }}$ adalah 0,266 dengan batas signifikan 5\%

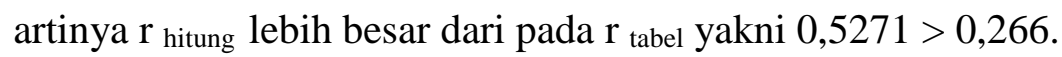

Dengan demikian nilai r product moment terdapat hubungan antara persepsi siswa tentang penguasaan guru terhadap materi pelajaran administrasi perkantoran dan motivasi belajar siswa administrasi perkantoran, dan t pada perhitungan taraf signifikan 0,05 dengan $\mathrm{dk}=\mathrm{N}-2=55$ juga terdapat pengaruh positif, terbukti $\mathrm{t}_{\text {hitung }}(4,5961)$ lebih besar dari pada $\mathrm{t}_{\text {tabel }}(2,000)$, yakni 4,5961 > 2,000 yang berarti $\mathrm{H}_{0}$ ditolak sedangkan $\mathrm{H}_{1}$ diterima.

Berdasarkan kriteria tingkat koefisien korelasi, diketahui $r$ hitung adalah 0,5271 yang berarti berada diantara 0,200 sampai dengan 0,399 maka dapat dikatakan bahwa persepsi siswa tentang penguasaan guru terhadap materi pelajaran administrasi perkantoran dan motivasi belajar siswa administrasi perkantoran kelas XII Administrasi Perkantoran di SMK Pelita Ciampea Kabupaten Bogor mempunyai hubungan dalam kriteria sedang.

\section{SIMPULAN DAN SARAN}

\section{A. Simpulan}

Berdasarkan hasil pengujian hipotesis penelitian, maka dapat ditarik kesimpulan sebagai hasil penelitian ini. Adapun yang penulis dapat simpulkan dari hasil penelitian ini adalah sebagai berikut:

1. Hasil penelitian ini membuktikan bahwa persepsi siswa tentang penguasaan guru terhadap materi pelajaran administrasi perkantoran dan motivasi belajar siswa administrasi perkantoran. Dengan nilai rata-ratanya (mean) sebesar 75,01 dalam 
persentasi 75,01 \%. Dengan demikian dibawah rata-rata sebesar 24,99\% dan diatas rata-rata sebesar 50,02\%. Maka dapat digolongkan berkriteria tinggi.

2. Berdasarkan hasil penelitian di atas, bahwa motivasi belajar siswa administrasi perkantoran. Dengan nilai rata-ratanya (mean) sebesar 69,26 dalam persentasi 69,26\%. Dengan demikian dibahwah rata-ratanya sebesar 30,74\% dan diatas rata-rata sebesar $38,52 \%$. Maka dapat digolongkan berkriteria tinggi.

3. Berdasarkan hasil perhitungan $\mathrm{t}$ hitung sebesar 4,5961 dan $\mathrm{t}$ tabel dengan derajat kebebasab $(\mathrm{dk})=\mathrm{N}-2$ dan $\alpha=0,05$ sebesar 2,000. Hal ini berarti $\mathrm{t}$ hitung lebih besar dari $t_{\text {tabel }}(4,5961>2,000)$. Hasil pengujian terhadap koefisien korelasi yang diperoleh dari hasil perhitungan bahwa $r_{x y}$ 0,5271 signifikan. Sehingga terdapat hubungan antara persepsi siswa tentang penguasaan guru terhadap materi pelajaran administrasi perkantoran dan motivasi belajar siswa administrasi perkantoran SMK Pelita Ciampea Kabupaten Bogor.

\section{B. Saran}

Berdasarkan kesimpulan dari hasil penulis mengajukan beberapa saran.

\section{Bagi Siswa}

a) Siswa hendaknya meningkatkan motivasi belajar khususnya motivasi intrinsik.

b) Siswa hendaknya memiliki cita-cita dan tujuan sebagai motivasi belajar.

\section{Bagi Guru}

a) Guru hendaknya terus meningkatkan kompetensinya sebagai guru yaitu kompetensi pedagogik, kompetensi kepribadian, kompetensi sosial dan kompetensi profesional.

b) Guru hendaknya meningkatkan kemampuan dalam mengelola metode pembelajaran.

c) Guru hendaknya mampu menumbuhkan motivasi belajar siswa.

\section{Bagi Sekolah}
a) Sekolah hendaknya meningkatkan fasilitas sarana dan prasarana demi menunjang kegiatan pembelajaran.
b) Sekolah hendaknya memperhatikan kinerja guru.
c) Sekolah hendaknya memperhatikan kebutuhan siswa. 


\section{REFERENSI}

Arikunto, Suharsimi. (2006). Prosedur penelitian. Jakarta: Rineka Cipta.

Asrori, Mohammad. (2009). Pisikologi Pembelajaran, Bandung; CV Wacana Prima.

Arsyad, Arsyad, \& Sulfemi, Wahyu Bagja. (2013). Pengaruh Persepsi Guru Tentang Kemampuan Manajerial Kepala Sekolah dan Kecerdasan Emosional Guru Terhadap Kinerja Guru (Studi Kasus Di SMK Muhammadiyah 6 Kabupaten Bogor). Fascho 2 (1), 1-9

Arsyad, Arsyad., \& Sulfemi, Wahyu Bagja. (2014). Minat Siswa Tentang Keadministrasian dengan Hasil Belajar Administrasi Perkantoran. Edutecno 9 (2), 40-50

Arsyad, Arsyad., \& Sulfemi, Wahyu Bagja. (2018) . Metode Role Playing Berbantu Media Audio Visual Pendidikan dalam Meningkatkan Belajar IPS. Jurnal Pendidikan Ilmu Pengetahuan Sosial Indonesia. 3 (2). 41 - 46.

Badar, Dadan Samsul dan Sulfemi, Wahyu Bagja. (2014). Pengaruh Rasa Percaya Diri dan Motivasi Berprestasi Terhadap Kinerja di Kecamatan Ciampea Kabupaten Bogor. Edutecno. 10 (1), 1-10,

Dimyanti dan Mujiono, (2010). Belajar dan Pembelajaran. Cet.IV. Jakarta: Rineka Cipta.

Fajartriani, Tia dan Sulfemi, Wahyu Bagja. (2014). Pengaruh Motivasi Kerja Guru dan Iklim Organisasi Terhadap Kinerja Guru SMA Negeri di Kecamatan Cigudeg. Edutecno. 8 (1), 17-26.

Rasyid, Harun. (2008). Penilaian hasil belajar, Cet. II. Bandung: CV Wacana Prima.

Rusman, (2012). Model-Model Pembelajaran. Cet Ke-5, Jakarta: PT. Raja Gofindo Persada.

Sardiman, A.M. 2011. Interaksi dan Motivasi Belajar Mengajar, Cet. 19. Jakarta: PT Raja Gopindo Persada.

Saud, Udin Syaefudin, (2011_. Pengembangan Profesi Guru Cet. IV. Bandung: Alfabeta.

Siregar, Evalina dan Nara, Hartini.(2010). Teori Belajar dan Pembelajaran. Cet. I. Bogor: Ghalia Indonesia.

Slameto, (2010. Belajar dan faktor-faktor yang mempengaruhi. Cet. 5. Jakarta: Rineka Cipta.

Sugiyono, (2012). Statistika Untuk Penelitian, Cet. 21. Bandung: Alfabeta.

Sulfemi, Wahyu Bagja. (2015). Pengaruh Metode Pembelajaran Kontekstual dan Penggunaan Media Video Pendidikan Terhadap Hasil Belajar IPS. Edutecno. 13 (2), 1,10 . 
Sulfemi, Wahyu Bagja. (2016). Hubungan antara Persepsi Guru pada Kepemimpian Kepala Sekolah dan Motivasi Guru dengan Kinerja guru dalam Proses Pembelajaran di SMA Negeri 1 Ciomas. Fascho : Kajian Pendidikan dan Sosial Kemasyarakatan, 5 (1), 36-55

Sulfemi, Wahyu Bagja. (2017). Analisis Pengaruh Motivasi Dan Disiplin Terhadap Kinerja Guru (Studi Kasus di SMA Negeri 1 Pamijahan Kabupaten Kabupaten Bogor). Prosiding Seminar Nasonal STKIP Muhammadiyah Bogor. 1 (1), 342-357

Sulfemi, Wahyu Bagja dan Supriyadi, Dede. (2018). Pengaruh Kemampuan Pedagogik Guru dengan Hasil Belajar IPS. Edutecno 17 (1), 1-10.

Sulfemi, Wahyu Bagja dan Nurhasanah. (2018). Penggunaan Metode Demontrasi dan Media Audio Visual Dalam Meningkatkan Hasil Belajar Peserta Didik Mata Pelajaran IPS. Jurnal Pendas Mahakam. 3 (2). 151-158.

Sulfemi, Wahyu Bagja dan Hilga Minati. (2018). Meningkatkan Hasil Belajar Peserta Didik Kelas 3 SD Menggunakan Model Picture And Picture dan Media Gambar Seri. JPSD. 4 (2), 228- 242.

Sulfemi, Wahyu Bagja dan Setianingsih. (2018), Penggunaan Tames Games Tournament (TGT) Dengan Media Kartu Dalam Meningkatkan Hasil Belajar. Journal of Komodo Science Education (JKSE. 1 (1), 1-14.

Sulfemi, Wahyu Bagja. (2018). Pengaruh Disiplin Ibadah Sholat, Lingkungan Sekolah, dan Intelegensi Terhadap Hasil Belajar Peserta Didik Mata Pelajaran Pendidikan Agama Islam. Edukasi: Jurnal Penelitian Pendidikan Agama dan Keagamaan. $16(2), 166-178$.

Sulfemi, Wahyu Bagja. (2018). Modul Manajemen Pendidikan Non Formal. Bogor : STKIP Muhammadiyah Bogor.

Sulfemi, Wahyu Bagja dan Desmiati, Zulaicha. (2018). Model Pembelajaran Missouri Mathematics Project Berbantu Media Relief Experience dalam Meningkatkan Hasil Belajar Siswa. Jurnal Pendas Mahakam . 3 (3), 232-245.

Sulfemi, Wahyu Bagja. (2019). Asosiatif Layanan Tenaga Perpustakaan Sekolah Dengan Motivasi Membaca Siswa di Kabupaten Bogor. Edutecno. 19 (2), 1-10.

Sulfemi, Wahyu Bagja. (2019). Manajemen Pendidikan Berbasis Multi Budaya. Bogor : STKIP Muhammadiyah Bogor

Sulfemi, Wahyu Bagja dan Mayasari, Nova. (2019), Peranan Model Pembelajaran Value Clarification Technique Berbantuan Media Audio Visual Untuk Meningkatkan Hasil Belajar IPS. Jurnal Pendidikan. 20. (1). 53-68.

Sulfemi, Wahyu Bagja., \& Yuliana, Desi. (2019). Penerapan Model Pembelajaran Discovery Learning Meningkatkan Motivasi dan Hasil Belajar Pendidikan Kewarganegaraan. Jurnal Rontal Keilmuan Pancasila dan Kewarganegaraan 5 (1), 17-30. 
Yusfiriadi, Yusfiriadi, \& Sulfemi, Wahyu Bagja. (2012). Penyelewangan Dana Dalam Dunia Pendidikan. Fascho 1 (1), 1-9. 